\title{
HOLOCENE LANDSCAPE INSTABILITY IN THE DAZZLER RANGE, NORTHERN TASMANIA
}

\author{
by Kevin Kiernan
}

(with two text-figures)

Kiernan, Kevin, 1998 (31:xii): Holocene landscape instability in the Dazzler Range, northern Tasmania. Pap. Proc. R. Soc. Tasm. 132: 35-40. https://doi.org/10.26749/rstpp.132.35 ISSN 0080-4703. Forest Practices Board, 30 Patrick Street, Hobart, Tasmania, Australia.

At least $5 \mathrm{~m}$ of poorly consolidated Quaternary sediments have accumulated since the mid Holocene in the lower reaches of stream channels that drain the flanks of the Dazzler Range. Radiocarbon assay of charcoal and wood fragments contained in the sediments indicate deposition during the mid to late Holocene 5.2-1.8 ka. Coarse gravels in the earliest deposits are believed to have been recycled from relict periglacial gravels in response to increased runoff and channel instability, brought about by neoglacial cooling coupled with changes in vegetation structure and associated fire frequency. The thickness of the sediments and the presence of large logs in the sediments along the lower reaches of Branchs Creek suggest at least one geomorphic event of high magnitude. Significant aggradation of finer calibre sediments has continued during the last two millenia. Since European settlement, deep gulleys have formed in the lower reaches of alluvial fans that flank the range, in response to land clearing for agriculture and the artificial straightening of stream channels. The earlier history of slope instability and sediment aggradation, even under natural conditions, highlights the need for careful land management.

Key Words: Tasmania Dazzler Range, Holocene, radiocarbon dating, fluvial geomorphology, periglaciation, slope stability, channel stability, land management.

\section{INTRODUCTION}

Aggradation in the form of valley fills and slope deposits dated to the mid to late Holocene has been reported from several parts of Tasmania. Some researchers have suggested there to have been a period of relative aridity in the mid Holocene and/or increased burning by Aborigines, in order to explain the catchment destabilisation necessary to cause aggradation of the magnitudes reported (Goede 1973, Davies 1974). Evidence has recently emerged that considerable mid to late Holocene aggradation has also occurred along the lower reaches of two of the principal streams that drain the Dazzler Range in central northern Tasmania. This paper addresses the nature and likely origin of these sediments, and considers their implications for land management in this area.

The Dazzler Range comprises a small system of hills and ridges that stretches NNW-SSE, commencing a few kilometres from the northern coastline of Tasmania and extending inland for $-20 \mathrm{~km}$ (fig. 1). The range is drained by streams that discharge eastwards into the lower Tamar River estuary, northwards into Bass Strait, and westwards into Port Sorell. It rises to just over $500 \mathrm{~m}$ altitude and comprises mainly sandstones, slates and phyllites of the Proterozoic Badger Head Group, with sands and gravels of Tertiary age flanking the range (Gee \& Legge 1970).

The climate of the Dazzler Range is moderated by its close proximity to Bass Strait, although conditions are likely to have been more arid during the low sea level stands of the Pleistocene, when much of Bass Strait was exposed as dry land, and the setting of the Dazzler Range was more continental than at present. The nearest stations from which present-day climatic data are available are Devonport East (46 m altitude), $23 \mathrm{~km}$ west of the Dazzler Range, and Low Head Lighthouse (28 m altitude), $10 \mathrm{~km}$ to the northeast of the range. Mean annual maximum and minimum temperatures are respectively $16.8^{\circ}$ and $8.1^{\circ} \mathrm{C}$ at Devonport and $16.1^{\circ}$ and $9.4^{\circ} \mathrm{C}$ at Low Head. Annual rainfall totals are significantly higher at Devonport East $(895.7 \mathrm{~mm})$ than at Low Head $(680.7 \mathrm{~mm})$. However, the highest daily recorded rainfall is from Low Head $(113.0 \mathrm{~mm}$ versus $86.6 \mathrm{~mm}$ at Devonport East).

The northernmost extremity of the Dazzler Range lies in the Asbestos Range National Park, but further inland most of the range has the status of State forest. Some freehold land is also present. Logging of some of the slopes and forest plantation development has occurred in recent decades. Clearing for agricultural purposes has extended onto some lower slopes since the earliest days of European settlement.

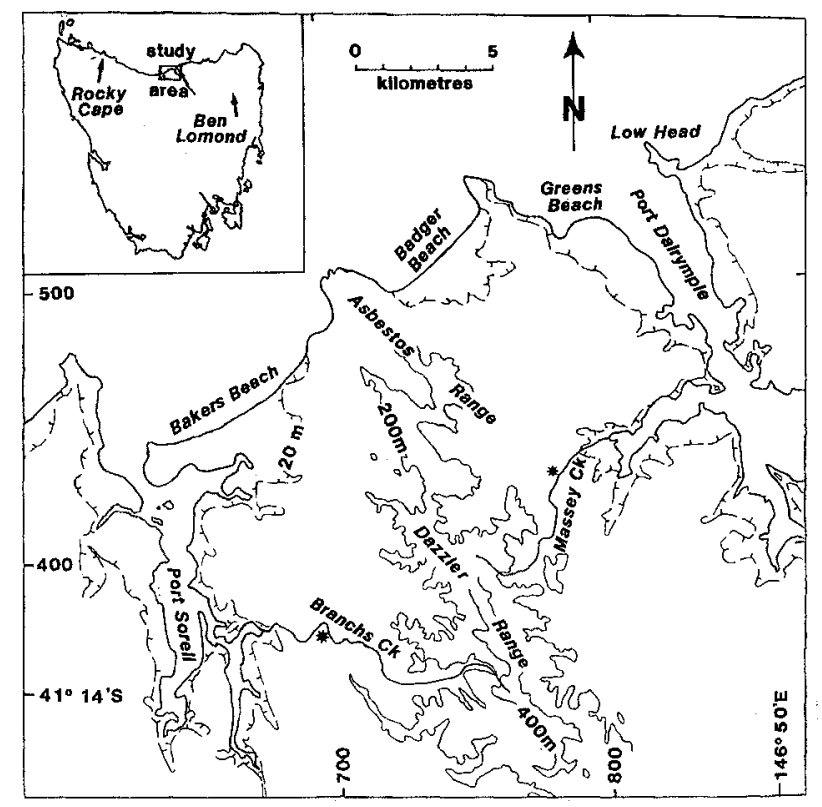

FIG. 1 - Location of the study area. 


\section{PREVIOUS RESEARCH IN THE DAZZLER RANGE AREA}

The catchments of the principal streams that drain the Dazzler Range remain forested in all but their lowermost reaches. The channels in this area appear to be stable, and deep natural sections that allow examination of the Quaternary stratigraphy are rare. However, the stratigraphy of some alluvial fans that flank the range is locally revealed in erosion gullies formed in pasture areas. The effect is most pronounced where channelisation of water flowing through formerly swampy ground has led to a significant increase in the erosive capacity of flows through the channel relative to that upstream. In such situations, massive gully erosion is common, if sediment supply from upstream is less than the erosive capacity of the flow downstream. Channel adjustment is achieved by bed and gully-head erosion and scour (Bird 1985, O'Loughlin 1991).

Given the relatively high altitude attained by the Dazzler Range and the presence of periglacial sediments close to sea level at Rocky Cape $-100 \mathrm{~km}$ to the WNW (Colhoun 1977), it seems reasonable to assume that periglacial activity is also likely to have played a significant role in landscape evolution here. However, there is no evidence of periglacial processes being active to any significant degree today. If the standard lapse rate of $0.6^{\circ} \mathrm{C} / 100 \mathrm{~m}$ (Cole 1975) is assumed, then the temperature data from Devonport East and Low Head Lighthouse suggest present-day mean annual maximum and minimum temperatures of $-13^{\circ}$ and $-8^{\circ} \mathrm{C}$ atop the Dazzler Range. However, assuming a mean annual temperature (MAT) $-6.5^{\circ} \mathrm{C}$ lower than now during the Last Glacial Maximum (LGM) (Colhoun et al. 1996), the Dazzler Range is likely to have been a strongly periglacial environment during the Glacial Climatic Stages of the Pleistocene. By analogy with slope deposits at Rocky Cape, where Colhoun (1977) has obtained five dates of 24.1$33.2 \mathrm{ka}$ for organic materials in alluvial fan deposits, some of the diamictons on the slopes of the Dazzler Range and some of the alluvial fans probably date from the LGM and are the product of periglacial activity.

Although the geomorphology of the Dazzler Range has been little studied, the coastal geomorphology and sediments at the northern end of the range have received some attention. A well-developed series of parallel sand beach ridges of Holocene age occurs at Bakers Beach on the western side of the range (Davies 1972). Chick (unpubl. data) has obtained dates of $31960+3400 /-2380$ yr BP (Gak 5620) for wave-worn peat masses derived from below low tide level at Badger Beach on the eastern side of the Dazzler Range (Colhoun 1985). He also obtained results of $7850 \pm 140$ yr BP (Gak 5621) for a peat bed at mid tide level and $8020 \pm 140 \mathrm{yr}$ BP (Gak 5622) for a peat bed at high tide level. Organic clay from a podsol beneath a dune formed on beach sands at Badger Beach (694471) gave a radiocarbon age of $15900 \pm 510 \mathrm{yr} \mathrm{BP}$ (Gak 5619). Fish \& Yaxley (1966: 171) have reported a radiocarbon age of $7380 \pm 100$ yr BP (NZ1219) for a portion of tree stump in an intertidal peat bed at Badger Beach (740507). These dates reflect exposure of the present sea floor during the Last Glacial Stage and its subsequent inundation during the Holocene transgression.

A little further east, Thom et al. (1981) have reported four radiocarbon dates from shell hash samples from Greens Beach at the mouth of the Tamar estuary: $6085 \pm 90 \mathrm{yr}$ BP (SUA 1297); $38765+2700 /-2015$ yr BP (SUA 1298);
$8005 \pm 90$ yr BP (SUA 1299); and $3770 \pm 70$ yr BP (SUA 1300 ). However, interpretation of shell hash dates is complicated by the fact that interglacial marine sediments were eroded and later redeposited with more recent material as Holocene marine transgression occurred (Colhoun 1986).

The height of the Last Interglacial shoreline in this area is unresolved. However, in view of evidence for $20-30 \mathrm{~m}$ of uplift around parts of the Tasmanian coastline since the Last Interglacial Stage (Murray-Wallace \& Goede 1995), coastal processes are also likely to have played a role in the evolution of some lower slopes, assuming comparable tectonic activity in the Dazzler Range area. Uplift of this order would imply marine inundation into the lowermost reaches of some valleys that drain westwards and eastwards from the Dazzler Range.

\section{BRANCHS CREEK SEDIMENTS}

Branchs Creek rises from $-500 \mathrm{~m}$ altitude and flows westwards into the South East Arm of Port Sorell, the estuary of the Rubicon River and the Franklin Rivulet. An alluvial fan with its apex at $-30 \mathrm{~m}$ altitude has formed $2 \mathrm{~km}$ from tidewater, at the break of slope at the foot of the range at -690373 (Tasmap 1:100 000 TAMAR, Sheet 8215) The meandering stream channel that formerly occured at the break of slope at the foot of the Dazzler Range has been artificially straightened during the course of pasture improvement.

Following a heavy rainfall event during the period 2-6 April 1989, an erosion gully which had formed across the alluvial fan in the lower reaches of Branchs Creek and had shown increased activity since the start of that year, extended rapidly headwards for $-300 \mathrm{~m}$. The erosion was focussed where the stream channel had been artificially straightened. Erosion of the gully led to the filling of a large farm dam downstream with sediment and also to damage to surrounding pasture. Insufficient data are available to allow the rainfall intensity responsible for this rainfall event to be calculated but, by analogy with flood discharge records for two nearby catchments, O'Loughlin (1991) suggested that the peak flow experienced in lower Branchs Creek was 21.8 cumecs, the recurrence interval for flows of this magnitude being -15 years.

From the dimensions and bed slope of the undisturbed channel immediately upstream from the eroded area, O'Loughlin (1991) calculated a bank-full flow velocity and discharge of $1.32 \mathrm{~m} / \mathrm{sec}$ and $8.0 \mathrm{cumec}$ respectively, compared to $5.22 \mathrm{~m} / \mathrm{sec}$ and 117.0 cumecs for the artificially modified section of channel. Discharge through the modified channel exceeded the capacity of the unmodified channel by a factor of 12 . Discharge in excess of 8 cumecs through the unmodified channel would result in overbank flow that would lead to dissipation of erosive energy across the vegetated floodplain, with negligible erosion potential (O'Loughlin 1991).

The gully that formed across the fan extended headward for several hundred metres, upstream from the pasture where the channel had been modified, into forested land. The gully was generally up to $5 \mathrm{~m}$ deep and $10 \mathrm{~m}$ wide. Towards its upstream end, sections up to $6 \mathrm{~m}$ deep were incised through the fan sediments, with large logs present at the base of some sections. The stratigraphy of the sediments exposed in the sections along the walls of the gully during the winter of 1991 is presented in figure 2 (A,B,C,D). 


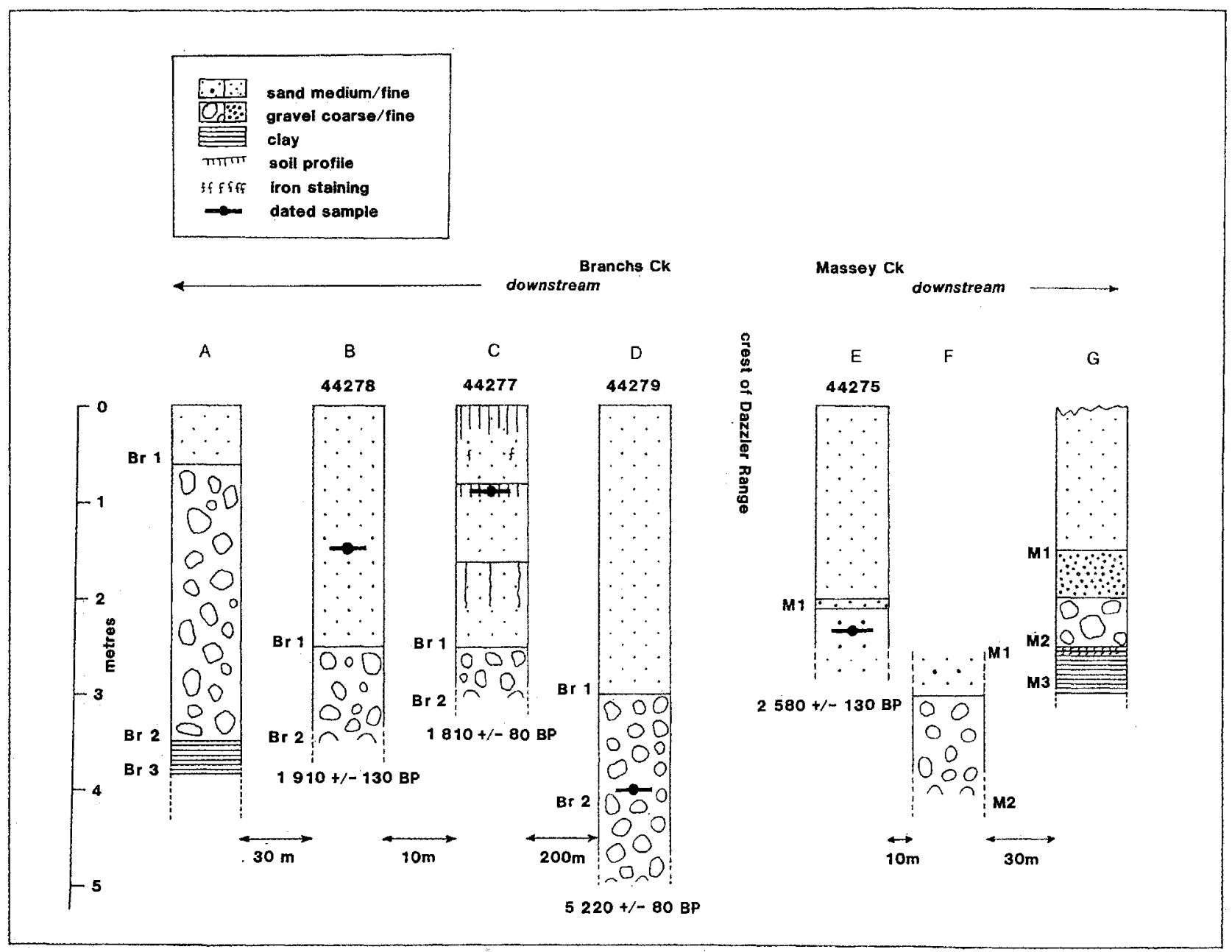

FIG. 2 - Sections through the Branchs Creek sediments $(A, B, C, D)$ and Massey Creek sediments $(E, F, G)$.

Unit Br1, the uppermost unit, comprises up to $3 \mathrm{~m}$ of sands. The upper $0.30 \mathrm{~m}$ or so comprises a soil profile of A-Cox-Cu type (Birkeland 1984) developed in the sands. In one section, poorly developed palaeosols were evident at $0.80-0.95 \mathrm{~m}$ depth, and possibly at $1.6-2.1 \mathrm{~m}$ depth, with light iron-staining of the sands in some cases evident at depths of $2 \mathrm{~m}$ or more. Lenses and beds of fine gravel a few centimetres thick were present, particularly towards the base of the unit. The mean calibre of these gravels is $<25 \mathrm{~mm}$, the largest clasts being $-50 \mathrm{~mm}$ in diameter.

Unit Br2 comprises a bed of coarse gravels at least $2 \mathrm{~m}$ thick. The clasts are commonly $0.10-0.15 \mathrm{~m}$ in diameter, the largest clast observed being $-1.4 \mathrm{~m}$ long. The gravels comprise sandstones and metamorphic rocks derived from further upstream within the Branchs Creek catchment. Similar gravels are exposed in streambank sections at up to $110 \mathrm{~m}$ altitude in several other locations for at least $7 \mathrm{~km}$ further upstream. Large pieces of wood, including logs $3-4 \mathrm{~m}$ long and up to $0.5 \mathrm{~m}$ diameter, occur within the uppermost part of this unit.

Unit Br3 consists of dense clay at least $1 \mathrm{~m}$ thick.

Organic material was retrieved for radiocarbon assay from three horizons in these alluvial sediments. Charcoal from within a palaeosol at $0.80-0.95 \mathrm{~m}$ depth in $2.5 \mathrm{~m}$ of unit $\mathrm{Br} 1$ sands gave an age of $1810 \pm 80 \mathrm{yr} \mathrm{BP}$ (Beta 44277). A sample comprising a combination of charcoal and wood fragments from $1.5 \mathrm{~m}$ depth in a $2.5 \mathrm{~m}$ thick exposure of unit $\mathrm{Br} 1$ sands gave an age of $1910 \pm 130 \mathrm{yr}$ $\mathrm{BP}$ (Beta 44278). A wood fragment from $1 \mathrm{~m}$ depth in an exposure of unit $\mathrm{Br} 2$ gravels overlain by $3 \mathrm{~m}$ of unit $\mathrm{Br} 1$ sands returned a radiocarbon age of $5220 \pm 80 \mathrm{yr} \mathrm{BP}$ (Beta 44279).

\section{MASSEYS CREEK SEDIMENTS}

Masseys Creek drains eastwards from the Dazzler Range to the West Arm of Port Dalrymple, the Tamar River estuary. Like Branchs Creek, Masseys Creek has formed an alluvial fan, the apex of which lies at $-30 \mathrm{~m}$ altitude, $-2 \mathrm{~km}$ from tidewater and $9 \mathrm{~km}$ inland from the northern coastline of Tasmania. In the lower reaches of Masseys Creek, a gully up to 3-4 $\mathrm{m}$ deep has formed within the alluvial fan on the lower slopes, following clearing and artificial straightening of the stream channel (Tamar 795438). The stratigraphy exposed is presented in figure $2(\mathrm{E}, \mathrm{F}, \mathrm{G})$.

Unit $M 1$, the uppermost, comprises up to $3.5 \mathrm{~m}$ of sand. In one section a $0.1 \mathrm{~m}$ thick lens of fine gravel occurred at $2 \mathrm{~m}$ depth, but in another section a $0.4-0.6 \mathrm{~m}$ thick bed of fine gravels was sandwiched between $1.6 \mathrm{~m}$ of sand and underlying coarse gravels.

Unit $M 2$ comprises coarse gravels in which some 
individual cobbles reached $0.1-0.15 \mathrm{~m}$ diameter. In one section at least $1 \mathrm{~m}$ of coarse gravels was exposed, while in another only half that thickness was present, sandwiched between $0.4-0.6 \mathrm{~m}$ of fine gravels, interpreted as part of unit $\mathrm{M} 1$, and an underlying clay bed. These gravels comprise Precambrian sandstone and metamorphic rocks from higher in the Masseys Creek catchment.

Unit $M 3$ comprised grey clay with some iron staining in the uppermost few centimetres.

A sample of charcoal and wood fragments was obtained from $2.2 \mathrm{~m}$ depth in unit M1, slightly below a $0.1 \mathrm{~m}$ thick bed of fine gravel. This returned a radiocarbon age of 2580 \pm 130 yr BP (Beta 44275).

\section{DISCUSSION}

From the catalogue of Tasmanian radiocarbon dates compiled by Colhoun (1985) it is evident that radiocarbon assay results of broadly comparable age have been obtained from wood and charcoal in alluvial sediments from a number of other parts of Tasmania. For example, Caine $(1978,1983)$ has reported a date of $3940 \pm 110$ yr BP (Beta 2109) for charcoal in slope deposits at Pig Run Creek at Ben Lomond in northeastern Tasmania. The results from the Dazzler Range also bear comparison with a major phase of gravel deposition from $-6.5 \mathrm{ka}$ to $-3 \mathrm{ka}$ in the Tea Tree Rivulet valley near Buckland in southeastern Tasmania (Goede 1965, 1973). However, the circumstances under which these sediments have accumulated remain unresolved.

The dated sequence of alluvial sediments at Branchs Creek on the western side of the Dazzler Range attests to considerable hillslope instability and alluvial sedimentation during the latter part of the Holocene. The very similar stratigraphy $12 \mathrm{~km}$ away, on the eastern side of the range at Masseys Creek, and the broadly similar age of the sediment there indicate that the aggradation at this time was not a localised phenomenon.

The radiocarbon date obtained from a log buried in the upper part of the Unit $\mathrm{Br} 2$ gravels is not entirely conclusive evidence for the age of the gravels. Nanson et al. (1995) found that logs of long-lived and rot resistant Huon pine (Lagarostrobos franklinii) in the present channel of the Stanley River in western Tasmania commonly yielded radiocarbon ages of up to $2 \mathrm{ka}$. While the longevity of the timber in the channel of Branchs Creek may be less than that of Huon pine logs in the Stanley River channel, the possibilty remains that the uppermost Branchs Creek gravels are significantly younger than the logs they contain. However, the possibility that contamination of the wood sample by younger humic acids may have given rise to an erroneously young date must also be allowed.

Weathering of the sandstone on some slopes of the Dazzler Range has produced small angular blocks that have been incorporated into slope deposits providing a ready source for the gravels along the valley bottoms. However, there is little to suggest that significant volumes of this material are being delivered into the stream channels today. Unit $\mathrm{Br} 2$ comprises clasts that are beyond the competence of the present stream to mobilise, other than under flood conditions. The presence of a considerable thickness of sands overlying the gravels along the floor of the Branchs Creek valley suggests that, under the present vegetation cover, coarse gravels are not normally being mobilised.
In more alpine environments, transitions from the aggradation of coarse alluvial gravels during the LGM to the deposition of only finer sands and gravels during the Holocene have commonly been interpreted as resulting from initially greater mechanical weathering and reduced slope stability, under colder and drier conditions when forest biomass was less than now, followed by the production of finer calibre weathering products after chemical weathering processes became more pronounced, under more stable, forested conditions, once the climate ameliorated (Colhoun 1982). A related situation has been reported from the Stanlcy River valley in lowland western Tasmania (Nanson et al. 1995). However, the radiocarbon evidence from lower Branchs Creek indicates that at least some of the gravels considerably postdate the LGM.

Mid to late Holocene reworking of clasts produced under earlier cold climate conditions seems a likely origin for these dated gravels, but a mechanism that would allow their liberation is required. Localised high magnituderelatively low frequency events, such as landslides, would have the potential to do so, but such activity appears to be infrequent in the Dazzler Range, where Grant et al. (1995) assessed the landslide risk to range from negligible to moderate, depending upon slope. While the gravels have been reworked to a limited degree during catastrophic erosion events, such as those responsible for incision of the Branchs Creek and Masseys Creek gullies, in some instances they have proved relatively resistant to erosion, even forming a small knickpoint waterfall at Masseys Creek.

Slope instability in response to tectonic activity is conceivable. Fire, perhaps anthropogenic, is another possibility. Hughes \& Sullivan (1981) have argued that Aboriginal burning could have been the major, if not sole cause of a major phase of landscape instability in eastern NSW in the late Holocene. However, there is no evidence to implicate Aborigines in the catchment instability evident in the Dazzler Range. The present vegetation suggests that parts of the Dazzler Range are an oasis of relatively low fire frequency at present (Brown \& Buckney 1983). Some analogy might be possible between the situation in the Dazzler Range in the past and present conditions inland of St Marys on Tasmania's east coast. There, dissected hills formed of Mathinna rocks exhibit wet sclerophyll and fern communities in protected gullies and much more open forest with limited ground cover and high fire frequencies on the north-facing slopes and ridges (F. Duncan, pers. comm.).

A climate-driven change towards a more open vegetation structure coupled with associated changes in fire frequency would provide a plausible explanation for the dated Unit $\mathrm{Br} 2$ gravels at Branchs Creek. Macphail (1981) argued that climate has predominated over fire in determining the nature of Tasmania's vegetation during the Holocene. Tasmanian palynological records have generally proved too insensitive to allow detailed insight into Holocene climatic events and, at any rate, they do not readily allow discrimination between changes in temperature and changes in rainfall. However, Macphail (1981) suggested that many Tasmanian forests became more open in structure and sclerophyll-enriched after $-7-6 \mathrm{ka}$, and that, during this period, climates became more variable, drought and frostprone. Markgraf et al. (1986) suggested that maximum Holocene precipitation levels in southwestern Tasmania were attained from 8-6 ka after which conditions became considerably drier. 
While some Holocene slope deposits and valley fills elsewhere in Tasmania have previously been attributed to a phase of mid Holocene aridity (Davies 1974), no convincing independent evidence for such a phase has been forthcoming. On the other hand, oxygen-isotope analysis of a speleothem from Lynds Cave at Mole Creek in central northern Tasmania indicates colder conditions than now during the late Holocene, with conditions of maximum cold at -3.8 ka (Goede \& Hitchman 1984). A further palaeotemperature record from a speleothem from Frankcombes Cave in the Florentine Valley, south central Tasmania, suggests temperatures were $2-3^{\circ} \mathrm{C}$ colder than now at $-4.1 \mathrm{ka}$, and were nearly as low on at least four other occasions between $3.8 \mathrm{ka}$ and $3.0 \mathrm{ka}$ (Goede et al. 1990). At similar southern latitudes in New Zealand, there is also evidence that the marked warming that occurred after $-9 \mathrm{ka}$ terminated with neoglacial cooling that commenced at $-5 \mathrm{ka}$. Numerous well-documented glacier fluctuations have occurred since that time, these advances having diminished only slightly in size towards the present (Chinn 1996). Such palaeoclimatic evidence points towards the possibility of temperature-driven vegetation changes and associated aggradation in the Dazzler Range during the mid-late Holocene.

The Dazzler Range is at present forested to its summit, the vegetation on the higher parts of the range being a complex of eucalypt forest including Eucalyptus delegatensis, with varying understorey, and rainforest. Assuming the standard lapse rate of $0.6^{\circ} \mathrm{C} / 100 \mathrm{~m}$ (Cole 1975), the suggested relative temperature depression of $3^{\circ} \mathrm{C}$ during the late Holocene would imply a shift in vegetation boundaries on the Dazzler Range by $-500 \mathrm{~m}$, all other factors being equal. While the E. delegatensis forest could be expected to move downslope, the summit of the range would not emerge above tree-line. Kirkpatrick \& Brown (1984) have identified the Dazzler Range as being one of seven centres of local higher plant endemism in Tasmania. They suggested that the species involved may have evolved before the Last Glacial, and, if so, probably occupied the same geological substrate during the colder and drier conditions that prevailed then. From this they conclude these species could be expected to tolerate much lower temperatures than at present. Infrequent extreme events may be more significant in eliminating elements of the vegetation than temperature decline alone, but in this scenario recovery is likely to be relatively rapid. Short-term vegetation removal by clear-fall forestry under present climatic conditions has not produced the degree of landscape instability evident from the Branchs Creek and Massey Creek deposits. It seems most probable that the recycling of relict gravels from the Dazzler Range to form unit $\mathrm{Br} 2$ was facilitated by an interaction between neoglacial cooling and the development of a more open vegetation structure.

Vegetation response is likely to lag behind climate change (Colhoun et al. 1991), and should rainfall increase more rapidly than the vegetation cover, a significant increase in runoff and sediment yield may result. Nanson et al. (1995) proposed that the advent of large trees on the banks of the Stanley River in western Tasmania and the subsequent accumulation of $\log$ debris in the channel would have increased flow resistance and reduced stream power, boundary shear stress and the grain size of the sediment load, during a period interpreted by Markgraf et al. (1986) as one of increased overall precipitation. The Stanley River appears to have stabilised in its present channel at $3.5-3.2 \mathrm{ka}$, with complete stabilisation in the channel occurring after this. This was interpreted by Nanson et al. (1995) as being the result not of any detectable vegetation change but of a change in climate and a reduction in flow regime evident from a decline in channel capacity and sediment texture.

The radiocarbon dating from the Dazzler Range implies that during the late Holocene only fine calibre sediment has been deposited upon the coarse gravels, albeit in abundance. The reduction in the calibre of the sediments seems most likely to have been related to vegetation changes. The abundance of charcoal in the upper sand units at both Branchs Creek and Masseys Creek suggests there was fire activity at various times during the period over which they accumulated. The presence of weakly developed buried palaeosols in the $\mathrm{Br} 1$ sands indicates that this unit was not deposited in a single event.

While the sands appear to postdate $-2 \mathrm{ka}$ their precise age is uncertain, since the radiocarbon deteminations were performed upon charcoal fragments that might considerably predate accumulation of the sediment within which they occur. For example, Blong \& Gillespie (1978) have shown that the age of charcoal being carried in the present flotation load of the McDonald River in NSW varies from $-650 \mathrm{yr} \mathrm{BP}$ for larger fragments to $-1550 \mathrm{yr}$ BP for more comminuted particles. The limited soil profile development in the sands adjacent to both Branchs Creek and Masseys Creek suggests some ongoing surface instability adjacent to both stream channels.

\section{CONCLUSIONS}

The age of the basal part of the coarse gravel fills in the Branchs Creek and Massey Creek valleys is unresolved, but at least the upper part of this unit appears to date from the mid Holocene. Likely explanations for the aggradation of coarse sediment in valleys draining the Dazzler Range at this time are slope instability and the reworking of older deposits, facilitated by a shift towards a more open vegetation structure caused by neoglacial cooling. However, there is insufficient data to confirm this as the causal factor. Fire has probably played a significant role in erosion and the aggradation of finer sediment since that time. The volume of sediment that has accumulated during the late Holocene in the lower Branchs Creek and Masseys Creek valleys, even under natural forested conditions, and the strong response of the stream channels on the lower slopes to artificial modification suggest that cautious land management is required in the Dazzler Range.

\section{ACKNOWLEDGEMENTS}

I am grateful to Fred Duncan, Andy North, Nathan Duhig, Eric Colhoun and Albert Goede for helpful discussions regarding various aspects of this work. I would also like to thank Mick Brown and an anonymous referee for comments on the manuscript. 


\section{REFERENCES}

BIRD, J.F., 1985: Review of channel changes along creeks in the northern part of the Latrobe River Basin Gippsland, Victoria, Australia. Z. Geomorphol. NF 55: 97-111.

BIRKELAND, P.W., 1984: SOILS AND GEOMORPHOLOGY. Oxford University Press, New York.

BLONG, R.J. \& GILLESPIE, R., 1978: Fluvially transported charcoal gives erroneous ${ }^{14} \mathrm{C}$ ages for recent deposits. Nature 271 : 739-741.

BRown, M. J. \& Buckney, R.T., 1983: Structural and floristic variation in the forest communities of the West Tamar, Tasmania. Pap. Proc. R. Soc. Tasm. 117: 135-152.

CAINE, N., 1978: Late Holocene instability on hillslopes in northeastern Tasmania. Search 9: 298.

CAINE, N., 1983: THE MOUNTAINS OF NORTHEASTERN TASMANIA. Balkema, Rotterdam.

Chrnn, T.J., 1996 The Southern Hemisphere glacial record Antarctica and New Zealand. In Banks, M.R. \& Brown, M.J. (Eds): CLIMATIC SUCCESSION AND GLACIAL HISTORY OF THE SOUTHERN HEMISPHERE OVER THE LAST FIVE MILLION YEARS. Pap. Proc. R. Soc. Tasm. 130(2): 17-24.

COLE, F., 1975: INTRODUCTION TO METEOROLOGY. Wiley, New York.

Colmoun, E.A., 1977: Late Quaternary fan gravels and slope deposits at Rocky Cape, northwestern Tasmania: their palaeoenvironmental significance. Pap. Proc. R. Soc. Tasm. 111: 13-28.

Colhoun, E.A., 1982: A comparison of the major effects of geomorphic processes in Tasmania during the Last Glacial Stage and the Holocene Stage. HOLOCENE RESEARCH IN AUSTRALIA. Occ. Pap. 33, Dep. Geogr., Fac. Mil. Stud., Univ. NSW, Duntroon.

Colmoun, E.A., 1985: Radiocarbon dates for Tasmania, 19561984. Pap. Proc. R. Soc. Tasm. 119: 39-54.

Colmoun, E.A., 1986: Field problems of radiocarbon dating in Tasmania. Pap. Proc. R. Soc. Tasm. 120: 1-6.

Colhoun, E.A., Van der Geer, G. \& Fitzsimons, S.J., 1991 : Late Glacial and Holocene vegetation history of Governor Bog, King Valley, western Tasmania, Australia. J. Quat. Sci. 6: 55-66.

Colhoun, E.A., Hannan, D.G. \& Kiernan, K., 1996: Late Wisconsin Glaciation of Tasmania. In Banks, M.R. \& Brown, M.J. (Eds): CLIMATIC SUCCESSION AND GLACIAL HISTORY OF THE SOUTHERN HEMISPHERE OVER THE LAST FIVE MILLION YEARS. Pap. Proc. R. Soc. Tasm. 130(2): 33-45.

DAVIES, J.L. 1972: GEOGRAPHICAL VARIATION IN COASTAL DEVELOPMENT. Oliver and Boyd, Edinburgh: 204 pp.

DAVIES, J.L. 1974: Geomorphology and Quaternary environments. In Williams, W.D (Ed.): BIOGEOGRAPHY AND ECOLOGY OF TASMANIA: Junk, The Hague: 17-27.
Fish, G.J. \& YAXleY, M.L., 1966: BEHIND THE SCENERY. Education Department, Tasmania.

GeE, R.D. \& LEGGE, P.J., 1970: BEACONSFIELD, TASMANIA. Tasm. Dep. Mines Geol Atlas I Mile Series, Sheet 30 $(8215 \mathrm{~N})$.

Goede, A., 1965: The geomorphology of the Buckland Basin. Pap. Proc. R. Soc. Tasm. 99: 133-154.

GoEdE, A., 1973: Floodplain stratigraphy of the Tea Tree Rivulet. Aust. Geogr. Stud. 11: 28-39.

Goede, A \& Hirchman, M.A., 1984: Late Quaternary climatic change: Evidence from a Tasmanian speleothem. In Vogel, J.C. (Ed.): LATE CAINOZOIC PALAEOCLIMATES OF THE SOUTHERN HEMISPHERE. Balkema, Rotterdam: 221-232.

Goede, A., VeeH, H.H. \& Aylfffe, L.K., 1990: Late Quaternary palaeotemperature records for two Tasmanian speleothems. Aust. J. Earth Sci. 37: 267-278.

Grant, J.C, Laffan, M.D., Hill, R.B. \& Neilsen, W.A., 1995: FOREST SOILS OF TASMANIA. Forestry Tasmania, Hobart: 189 pp.

Hughes, P.J. \& SulLivan, M.E., 1981: Aboriginal burning and late Holocene geomorphic events in eastern NSW. Search 12(8): 277-278.

KIRKPATRICK, J.B. \& BROWN, M.J., 1984: The palaeogeographic significance of local endemism in Tasmanian higher plants. Search 15 (3-4): 112-113.

MaCPhail, M.K., 1981: A history of fire in the forest. In Kirkpatrick, J.B. (Ed.): FIRE AND FOREST MANAGEMENT IN TASMANIA:. Tasmanian Conservation Trust, Hobart: 15-22.

Markgraf, V., Bradbury, J.P. \& Bushby, J.R., 1986: Paleoclimates in southwestern Tasmania during the last 13,000 years. Palaios 1: $368-380$.

Murray-Wallace, C. V. \& Goede, A., 1995: Aminostratigraphy and electron spin resonance dating of Quaternary coastal neotectonism in Tasmania and the Bass Strait islands. Aust. J. Earth Sci. 42: 51-67.

Nanson, G.C., Barbetti, M. \& Taylor, G., 1995: River stabilisation due to changing climate and vegetation during the late Quaternary in western Tasmania, Australia. Geomorphology 13: 145-158.

O'Loughin, E.M., 1991: Erosion in Branchs Creek. Unpub. rep. to and available from For. Commn, Tasmania, 24 Jul. 1991: 6 pp.

Thom, B.G., Bowman, G.M., Gillespie, R., Temple, R. \& BARBETTI, M., 1981: RADIOCARBON DATING OF HOLOCENE BEACH-RIDGE SEQUENCES IN SOUTHEAST AUSTRALIA. Monogr. 11, Dep. Geogr., Univ. NSW R. Mil. Coll., Duntroon.

(accepted 3 February 1998) 